\section{Re: Når pasienten har en sjelden diagnose}

Stein Are Aksnes \& Kristian E. Kristoffersen har i Tidsskriftet nr. 5/2016 noen viktige poenger om pasienter med sjeldne diagnoser (1). Under arbeidet med etablering av nasjonal kjernejournal ble det tidlig klart at det er noen diagnoser som bør vurderes som spesielt kritiske. Dette er tilstander som man i en akuttsituasjon, f.eks. på legevakt, lett kan overse fordi de vanligvis ikke er med i den normale vurderingen av mulige diagnoser. Disse pasientene kan derfor lett feilvurderes og feilbehandles. En del pasienter med sjeldne diagnoser faller inn under kategorien «kritisk tilstand».

Med etableringen av kjernejournal har man fått mulighet til å varsle helsepersonell som ikke kjenner pasienten fra før om disse diagnosene. For et utvalg av diagnosene er det i kjernejournalen lagt inn direkte link til Helsebibliotekets oversiktssider, med videre referanser til opplysninger om tilstandene. En lege som møter en pasient med en slik diagnose for første gang, kan via kjernejournalen med noen få klikk få opplysninger om hvilken sjelden tilstand pasienten har og hvordan dette bør håndteres. Direktoratet for e-helse har fått nyttige innspill fra Nasjonal tjeneste for sjeldne sykdommer ved Stein Are Aksnes om disse diagnosene.

\section{Bent Asgeir Larsen}

bent@karrestad.no

Bent Asgeir Larsen (f. 1955) er fastlege og konsulent i Direktoratet for e-helse.

Ingen oppgitte interessekonflikter.

\section{Litteratur}

1. Aksnes SA, Kristoffersen KE. Når pasienten har en sjelden diagnose. Tidsskr Nor Legeforen 2016; 136: 408.

\section{Re: Tidsskriftet og manusforfatterne}

Det er et alvorlig signal til redaksjonen når en flittig bidragsyter til Tidsskriftet, Knut Gjesdal, opplever at manuskriptbehandlingstiden i Tidsskriftet er for lang (1). Problemet har dessverre vedvart uendret i mange år, slik Sellevold \& Bratlid viste allerede i 2010 (2). Siden den gang har det blitt iverksatt flere tiltak for å få ned behandlingstiden. Når dette i for liten grad har lyktes, skyldes det flere forhold, dels eksternt, men først og fremst internt i redaksjo- nen. Vi vurderer fortløpende de interne rutiner for manuskripthåndtering. En nylig gjennomgang viste gledelig nok en nedadgående trend for behandlingstid i 2015. Det er imidlertid helt nødvendig for Tidsskriftets posisjon og attraktivitet som publiseringskanal at det blir ytterligere bedring i 2016. For å lykkes i dette har vi gjort flere rutineendringer de siste måneder. Gjesdals ferske erfaring viser likevel med all tydelighet at vi fortsatt har en stor jobb foran oss med å forbedre service og hurtighet.

Gjesdal utfordrer også redaksjonen til å ta en diskusjon om hva det faglige innholdet bør være. Han nevner bokanmeldelser, der han mener behandlingstiden er rask, men at antallet er for stort. Det siste er redaksjonen enig i. For noen måneder siden strammet vi derfor kraftig inn på kriteriene for hvilke bøker som bør anmeldes i Tidsskriftet. Når det gjelder omtale av internasjonale artikler, følger vi i hovedsak «de fem store» av de internasjonale generelle medisinske tidsskriftene, og velger ut de artikler vi mener vil kunne ha størst interesse for den jevne norske lege. Erfaringen er at dette er svært populært stoff blant leserne.

Norske leger skal fortsette å ha et nasjonalt samlende fagtidsskrift av høy kvalitet. Det krever en våken og bevisst redaksjon samt dedikerte fagvurderere og forfattere som finner det attraktivt å publisere i norske legers eget tidsskrift. Men nasjonale medisinske tidsskrifter verden over opplever fallende tilfang av gode originale vitenskapelige studier. Tidsskriftet er intet unntak. Årsakene er komplekse, men raskere behandlingstider i spesialtidsskrifter og rent nettbaserte tidsskrifter er blant dem (3). I redaksjonen har vi en løpende debatt om hvordan også denne utfordringen skal møtes. Raskere behandlingstid er et åpenbart tiltak.

\section{Are Brean}

are.brean@legeforeningen.no

Are Brean (f. 1965) er sjefredaktør i Tidsskriftet.

Ingen $\varnothing$ vrige interessekonflikter.

\section{Litteratur}

1. Gjesdal K. Tidsskriftet og manusforfatterne. Tidsskr Nor Legeforen 2016; 136: 594.

2. Sellevold OF, Bratlid D. Har Tidsskriftet for lang publiseringstid? Tidsskr Nor Legeforen 2010; 130: 1228-31.

3. Smith R. The death throes of national medical journals. The BMJ blogs 2.3 .2016 http://blogs.bmj.com/bmj/2016/03/02/richard-smith-the-death-throes-ofnational-medical-journals/ (1.4.2016). 